\title{
Stem cells and cardiac repair: alternative and multifactorial approaches
}

\author{
Lamiaa A. Ahmed \\ *Correspondence: lamiaahmed@Staff.cu.edu.eg \\ Department of Pharmacology and Toxicology, Faculty of Pharmacy, Cairo University, Egypt.
}

\begin{abstract}
Severe myocardial infarction can lead to ventricular remodelling and progressive contractile dysfunction with inability of the heart to maintain perfusion to vital organs. Pharmacological and surgical interventions can only alleviate symptoms or retard further disease progression. However, these interventions fail to regenerate dead myocardium. Stem cells have the potential to replace or repair dead or injured cells after myocardial infarction. Stem cells are either integrated by themselves or provide a platform to transmit molecular signals to a target tissue without actually integrating into the tissue itself. Clinical studies, still in early stages, have reported that this therapeutic modality may lead to an overall improvement of cardiac function. Endogenous cell homing presents a promising approach that may represent an effective alternative to stem cell transplantation. Identifying factors and adequate regulation of signalling between bone marrow, peripheral circulation and infarcted myocardium are important in orchestrating the process of mobilization, incorporation, survival, differentiation and proliferation of stem cells. Moreover, the potential for magnifying stem cell-mediated paracrine effects using "genetically engineered", "preconditioned", "targeted" or "combined stem cell therapies" can provide promising options for enhancing stem cell therapy success while limiting adverse effects. It is hoped that these experimental trials will be eventually translated into successful treatment strategies in the clinical field.
\end{abstract}

Keywords: Cardiac repair, homing, mobilization, regeneration, stem cells

\section{Introduction}

Severe myocardial infarction (MI) can lead to ventricular remodelling and progressive contractile dysfunction with inability of the heart to maintain perfusion to vital organs [1]. The cardiomyocytes primarily respond to ischemia by cellular hypertrophy rather than proliferation, due to the limited regenerative ability of adult cardiomyocytes [2]. Moreover, post-infarction remodelling is likely an important trigger for initiating ventricular arrhythmias [3]. Therefore, post-infarction consequences remain a major contributor to cardiac morbidity and mortality. Pharmacological and surgical interventions can only alleviate symptoms or retard further disease progression. However, these interventions fail to regenerate dead myocardium. Consequently, in spite of the reduced mortality by current therapies, the increased morbidity due to the possible deterioration of heart function still remains a challenge [4].

Stem cells represent an important building block for regenerative medicine and tissue engineering. Theoretically, stem cells are capable of self renewal and differentiation into almost any tissue with specialized structure and function [5]. Stem cells, therefore, have the potential to replace or repair dead or injured cells after MI. Stem cell therapy also has brought a bright prospect for the treatment of heart failure [6]. Stem cells are either integrated by themselves or provide a platform to transmit molecular signals to a target tissue without actually integrating into the tissue itself [7]. Although preclinical research has documented the therapeutic potential of stem cells, clinical studies, still in early stages, have reported that this therapeutic modality may lead to an overall improvement of cardiac function [8].

\section{Stem cells subtypes \\ Embryonic stem cell}

Embryonic stem cells are isolated from the embryo at the blastocyst stage and can be fully differentiated into different cells including cardiomyocytes. A side from ethical issues, there is a limitation in the use of embryonic stem cells in clinical studies because of the possibility of teratoma formation [9].

\section{Somatic stem cells}

Somatic stem cells are derived from adult somatic tissue, such as bone marrow, adipose tissue, peripheral blood, umbilical cord blood, and skeletal muscle. Although somatic stem cells may be autologous and no immunological or ethical constraints exist, they have lower regenerative potential than embryonic stem cells [10].

\section{Bone marrow stem cells}

Bone marrow mononuclear cells (BM-MNCs) not only comprise hematopoietic stem cells (HSCs), but also

(c) 2013 Lamiaa A. Ahmed licensee Herbert Publications Ltd. This is an Open Access article distributed under the terms of Creative Commons Attribution License (http://creativecommons.org/licenses/by/3.0). This permits unrestricted use, distribution, and reproduction in any medium, provided the original work is properly cited. 
provide a hideout for a heterogeneous population of stem/progenitor cells; mesenchymal stem cells (MSCs) and endothelial progenitor cells (EPCs) [11]. The niche, in which bone marrow stem cells remain quiescent, is comprised of a diverse population of stromal cells and extracellular matrix components, such as fibronectin, collagens and proteoglycans [12]. The contractile potential of adult cardiomyocytes was shown to be preserved by BM-MNCs conditioned media. In addition, microvessel density and fractional shortening of myocytes incubated with BM-MNCs supernatants were better preserved than myocytes cultured in control medium [13]. BM-MNCs delivery to ischemic tissue has also demonstrated a significant increase in tissue levels of angiogenic ligands such as basic fibroblast growth factor (bFGF), vascular endothelial growth factor (VEGF), cardiac levels of interleukin-1 beta (IL-1 $\beta$ ) and tumor necrosis factor-a (TNF-a) [14].

In patients with MI, BM-MNCs that were directly infused to related artery infarction through angioplasty balloon catheter significantly improved left ventricular ejection fraction after 6 months. However, there were no significant differences compared with the control group after 18 months. In 5-year follow up, all indicators (cardiac index, exercise capacity, oxygen uptake, and left ventricular contractility) showed no differences with the control group [15]. Moreover, number and proliferation of stem cells were found to decline in elderly patients. This may be one reason for the lower outcomes of clinical trials in old patients with extensive comorbidities compared to animal studies [6]. On the other hand, a meta-analysis suggests that BM-MNCs therapy is likely more effective in ageing and diabetic individuals [16]. This may be explained on the basis that patients who are ageing or diabetic likely suffer from impaired endothelium or inadequate physiological angiogenesis in response to ischemia and therefore tend to gain beneficial effects from the supplementation of BM-MNCs [6].

\section{Mesenchymal stem cells}

MSCs are multipotent adult stromal stem cells that differentiate into a variety of tissues including muscle, cartilage, bone, skin, and fat. MSCs have been demonstrated to secrete factors such as angiopoietins, VEGF, bFGF, and hepatocyte growth factor (HGF) that protect the heart from ischemic insult by activation of neovascularization, improvement of contractility and bioenergetics and attenuation of fibrosis [17]. MSCs transplantation has been found to attenuate protein production of TNF-a and IL- 6 and increase anti-inflammatory cytokines expression through inhibition of nuclear factor-kappa B (NF-KB) activation [18]. MSCs also improve cardiac function through upregulation of antifibrotic HGF expression and transcriptional downregulation of types I and III collagen syntheses and matrix metalloproteinase (MMP) 2 and 9 [19]. In addition, an improvement in hemodynamics has been demonstrated in Akt-MSCs-treated hearts. This leads to a decrease in catecholamine levels and a subsequent attenuation of $\beta$-adrenoceptor downregulation [20]. Specifically, in a previous study, direct injection of MSCs into ischemic rat myocardium decreased fibrosis, apoptosis and left ventricular dilatation. This resulted in the alleviation of systolic and diastolic cardiac dysfunction with no significant effect on myocardial regeneration [21].

\section{Endothelial progenitor cells}

Progenitor cells have shown to be of most benefit when used to treat hibernating cardiomyocytes. Incorporated progenitor cells, through the release of growth factors, promote angiogenesis by acting on mature endothelial cells of limited regenerative potential leading to an improvement in oxygen supply [22]. VEGF and stromal derived factor-1 (SDF-1) released by EPCs into conditioned media promote the migration of mature endothelial cells and the formation of capillaries via differentiation-independent mechanisms [23]. Interestingly, the neutralization of VEGF, HGF, IL-8 and MMP-9 did not attenuate the cytoprotective effects of EPCs in a previous study. This provides an evidence that EPCs may exert their influence via alternative mechanisms likely related to intracellular antioxidant pathways [24].

\section{Cardiac stem cells}

Cardiac stem cells (CSCs) are cells that reside in the heart itself and are inherently programmed to reconstitute cardiac tissue. Resident CSCs have the ability to proliferate and differentiate into cardiomyocytes and, to a lesser extent, into smooth muscle cells and endothelial cells [25]. Many kinds of CSCs can be isolated and identified from adult heart including c-kit+ cells and Sca-1+ cells. CSCs have been found in clusters of an average density of $0.01 \%$ in the rat adult myocardium [26]. These cells have long telomeres, or "caps," on their chromosomal ends indicating a significant growth reserve [27]. It seems that CSCs account for physiological turnover in absence of injury. Thus, although not enough, they have the potential to rescue the infarcted heart. For stem cell therapy, these cells need to be harvested, cultured and delivered to the infarcted heart [28]. In a previous study, injection of CSCs into infarcted myocardium revealed an increase in expression of Akt, a decrease in caspase 3 activity and apoptosis, and an increase in capillary density. On the other hand, direct differentiation of CSCs accounted only for a small portion of new capillaries and cardiomyocytes [29]. Other study showed that intracoronary administration of cKit+ CSCs into rat hearts following acute ischemia induced proliferation of resident cKit+ CSCs in the infarct zone presumably through a paracrine mechanism [30].

\section{Mobilization versus transplantation}

Adult stem cells can be harvested and injected locally into the infarcted recipient. However, the ex vivo expansion of 
stem cells and their in vivo delivery are restricted by the limited availability of stem cell sources, the excessive cost of commercialization and the anticipated difficulties of clinical translation and regulatory approval. In addition, 90\% of the stem cells die within 24 hours after transplantation and less than $1 \%$ of systemically administered stem cells persist for longer than a week following injection [31]. Moreover, the majority of the cells move to preferred homing places including liver, spleen, lung, bladder, and brain and account for the very small amount of stem cells reaching the infarcted myocardium [32]. One means of overcoming this limitation would be to deliver stem cells directly to the injured area of the heart [33].

Endogenous cell homing is a simple approach that sounds truly fascinating because it can bypass the difficulties faced by stem cell transplantation. Homing normally refers to a stem cell's ability to find its way to a particular anatomic destination, often over great distances, from the bone marrow via the bloodstream [34]. A case in which a male patient received a heart from a female donor showed that Y-chromosome containing cardiomyocytes had integrated into the myocardium and made up 7 to $10 \%$ of those in the donor hearts and were highly proliferative. Therefore, circulating bone marrow-derived cells can be recruited to the injured heart and differentiate into cardiomyocytes [35]. Myocardial regeneration via stem cell mobilization at the time of infarction is known to occur, but the mechanism for this cellular homing and its clinical applications for the treatment of ischemic cardiomyopathy are unconfirmed. The use of the host as a bioreactor to recruit endogenous cells for therapeutics may reduce many medical costs [33]. Homing is a multistep cascade including the initial adhesion to activated endothelium or exposed matrix via selectin, transmigration through the endothelium and finally, migration and invasion of the target tissue. The guided mobilization of specific stem cell populations from bone marrow can be manipulated by altered expression of cytokines and growth factors to improve their local reparative capacity in the infarcted myocardium [2]. The administration of growth factors such as insulin-like growth factor-1 (IGF-1) and HGF and the use of some drugs that increase the secretion of these factors have been demonstrated to regulate activation, growth and migration of endogenous CSCs to repair the infarcted heart $[36,37]$. In addition, the activation of endogenous CSCs by paracrine factors released by engrafted stem cell may at least partly account for the beneficial effects after cell transplantation [38].

\section{Signalling factors}

Identifying factors and adequate regulation of signaling between bone marrow, peripheral circulation and infarcted myocardium are important in orchestrating the process of mobilization, homing, incorporation, survival, proliferation and differentiation of stem cells leading to cardiac protection, neovascularization, remodeling, metabolism and regeneration [19]. Factors that are important for mobilizing and chemotactic abilities include SDF-1, granulocyte colonystimulating factor (G-CSF), stem cell factor (SCF), IL-8 and VEGF. Factors that are expressed after $\mathrm{MI}$ and are involved in the patho-physiological healing process include TNF- $a$, IL-8, IL-10, Hypoxia-inducible factor-1 (HIF-1), VEGF and G-CSF. Signaling factors that are involved in differentiation, proliferation and survival process of stem cells include VEGF, erythropoietin (EPO), transforming growth factor -beta (TGF- $\beta$ ), HGF, HIF-1 and IL-8 [2].

\section{Granulocyte colony-stimulating factor and stem cell factor}

G-CSF, currently the most widely used agent in clinics for SC mobilization, affects both the mechanisms of SC mobilization as well as the release of further cytokines and growth factors [39]. G-CSF/SDF-1 have been found to increase proangiogenic cells such as angiogenic macrophages and EPCs, which may eventually contribute to neovascularisation [40]. G-CSF is not only associated with stem cell mobilization, but is also known to stimulate the development of committed progenitor cells into traditional hematopoietic cells, mainly granulocytes and macrophages [41]. A higher incidence of in-stent restenosis has been demonstrated when using G-CSF alone or in combination with intracoronary infusion of collected peripheral blood stem cells [42]. An increase in influx and maturation of inflammatory cells is detrimental in the absence of a proper regulatory mechanism, and therefore forms a conceivable disadvantage of G-CSF treatment. Therefore, as G-CSF is a pro-inflammatory factor, the use of G-CSF should be cautiously considered [43].

\section{Stromal derived factor-1}

SDF-1, also known as CXCL12, is released under the control of HIF-1, through interaction with its receptor (known as CXCR4 or CD184). There is a disruption in the link between HIF-1 and SDF-1 by accumulation of p53 [44]. The release of SDF-1 is modulated by different cytokines such as soluble kit ligand and VEGF-A. SDF-1 regulates angiogenesis in part by recruiting EPCs from bone marrow niches to ischemic tissues [45]. In addition, SDF-1 induces upregulation of MMP-9 activity, which causes shedding of soluble kit ligand and thereby liberates c-Kit positive stem cells into the circulation [46]. SDF-1 and its receptor CXCR4 are crucial in orchestrating stem cell mobilization to the ischemic myocardium. SDF-1-CXCR4 axis is involved in the chemoattraction of bone marrow-derived cardiac progenitor cells after MI [47]. Therefore, upregulation of both factors is pivotal in the repair mediated by stem cells.

\section{Stem cell factor}

SCF, a soluble kit ligand, binds to c-kit (also known as CD117), a receptor that is expressed on the surface of stem cells and 
has chemoattractant effects on these cells [43]. Activation of proteases, like cathepsins and MMPs, liberates SCF from the stroma and thereby promote activation, maturation and translocation of c-kit+cells from the endosteum to the vascular compartment of bone marrow [48]. SCF is downregulated in the heart after $\mathrm{MI}$, which is unfavorable for homing of BMSCs to the damaged heart. Elevated level of SCF in the circulation would enhance mobilization, incorporation, proliferation, differentiation and survival of BMSCs in the infarcted heart, which are essential steps in stem cell-mediated repair [2].

\section{Fibroblast growth factor}

FGF is speculated to maintain MSCs self-renewal. bFGF- 2 is one of the FGF families of heparin-binding growth factors. FGF- 2 exerts its proangiogenic activity through interactions with various endothelial cell surface receptors including tyrosine kinase receptors and integrins [49]. Unlike VEGF, FGF enhances angiogenesis via protein kinase C-mediated activation of mitogen activated protein kinase (MAPK) pathways, in nitric oxide (NO)-independent manner, thus providing an additional target for pharmacotherapy in cardiac tissue [43].

\section{Hepatocyte growth factor}

The mechanism of HGF in the repair mediated by stem cells lies in its ability to create an adhesive microenvironment in the heart after recruitment of stem cells there [50]. HGF seems to be a promising factor in cardiac repair. In a previous study, HGF was found to increase survival of cardiomyocytes after oxidative stress, and thereby reduce apoptosis. When overexpressed, HGF increases angiogenesis and improves the function of the infarcted heart. Furthermore, HGF is involved in anchoring stem cells to the ischemic myocardium, where HGF promotes adhesion, survival and proliferation of the BMSCs [2].

\section{Vascular endothelial growth factor}

VEGF is a strong promoter of angiogenesis in addition to its capability of mobilizing BMSCs into the peripheral blood in patients with MI. The maintenance, differentiation and expansion of stem cells have been attributed in part to VEGF [51]. An example for that is the mobilization of $M S C s$ in response to injury which is correlated with the increased concentrations of VEGF and G-CSF in peripheral blood [48]. VEGF production is regulated through HIF-1 in ischemic tissues [52] and in turn is a regulator of SDF1. VEGF-A, the most potent member of VEGF family, has been identified as one of the major growth factors that are involved in neovascularisation [43]. One of the important VEGF-activated signalling pathway is NO release. NO is a downstream signalling pathway of VEGF-activated endothelial proliferation and angiogenesis. Long-term VEGF stimulation induces an increase in the level of endothelial nitric oxide synthase (eNOS) expression. On the other hand, short-term stimulation promotes subsequent NO production via activation of the MAPK cascade, which plays a critical role in angiogenesis [53].

\section{Tumor necrosis factor-alpha}

The role of TNF-a in stem cell mobilization is complex and variable. TNF-a overexpression seems to have an early role in increase of infarct size [54]. However, a study demonstrated a chemoattractive response of stem cells towards TNF-a [2]. Usage of TNF-a in stem cell mediated cardiac repair can be valuable if timed and located correctly, but can be deleterious, if not.

\section{Interleukin-8}

Besides its inflammatory effect, IL-8 can induce stem cell mobilization. IL-8 production may be also of importance in G-CSF induced stem cell mobilization [55]. In absence of either neutrophils or MMP-9, IL-8 induced BMSC mobilization has been found to be reduced [56].

\section{Directions for enhancement of stem cell therapy}

The use of endogenous stem cell therapy today is limited by ineffective stem cell homing leading to insufficient populations of stem cells at the damaged areas [57]. Recent researches have identified many drugs, peptides, proteins, and various factors that increase the number and functional activity of stem cells (Table 1).

Combined pharmacological and stem cell therapy Administration of combined drugs therapy can improve the mobilization, incorporation, viability, differentiation and proliferation of stem cells.

\section{Statin}

Statins can induce stem cell mobilization via the PI3K/Akt/ eNOS pathway. Statins exhibit pro-angiogenic effects at low to medium dosage (activation of Akt/eNOS signaling) and at high dosage, they induce endothelial cell apoptosis (enhanced prenylation of GTPases) [58]. Statin mediates its beneficial effects on LV remodeling via its effect on eNOS activity. This was supported by a previous study after MI where statin therapy reduced cardiomyocyte hypertrophy and interstitial fibrosis and improved LV function to a substantially greater extent in wild-type mice as compared with eNOS-deficient mice [59]. In addition, statin therapy augmented eNOS activity in patients with congestive heart failure (CHF) independent of its effects on LDL cholesterol [60]. These favourable effects may be attributed to increased levels of VEGF and its antiapoptic effects on EPCs [43]. Statins might favourably influence EPCs function through an anti-inflammatory mechanism. Statins were also found to reduce C-reactive protein levels and exert beneficial effects in earlier stages of heart failure. In contrast, these beneficial effects are likely limited in elderly patients with advanced CHF and established 
Table 1. Directions for enhancement of stem cell therapy.

\begin{tabular}{|c|c|c|c|}
\hline Method & Model & Effect & References \\
\hline \multicolumn{4}{|l|}{ Pharmacological } \\
\hline \multirow[t]{3}{*}{ - Statin } & MI in mice & Decreased cardiomyocyte hypertrophy & {$[58]$} \\
\hline & & Decreased interstitial fibrosis & \\
\hline & & Improvement of LV function & \\
\hline - ACE inhibitors & $\mathrm{MI}$ in rats & Enhancement of bone marrow stem cell migration & {$[60]$} \\
\hline \multirow[t]{2}{*}{$-\mathrm{EPO}$} & $\mathrm{CHF}$ in rats & Increased neo-vascularization & {$[62]$} \\
\hline & & Increased proliferation and mobilization of BMSCs & \\
\hline \multirow[t]{3}{*}{ - Calcium channel blockers } & Patients with hypertension & Increased CD34+ progenitor cells & {$[61]$} \\
\hline & & Improvement of endothelial function & \\
\hline & & Decreased oxidative stress status & {$[65]$} \\
\hline $\begin{array}{l}\text { - Complement components } \\
\text { (C1q, C3a and C5) }\end{array}$ & complement-deficient mice & $\begin{array}{l}\text { Increased liberation and recruitment of progenitor } \\
\text { cells }\end{array}$ & {$[66]$} \\
\hline - $\beta 2$ adrenergic agonist & $\begin{array}{l}\text { Severe combined immunodeficient } \\
\text { (NOD-SCID) mice }\end{array}$ & $\begin{array}{l}\text { Increased liberation and mobilization of stem cells } \\
\text { induced by G-CSF }\end{array}$ & {$[67]$} \\
\hline \multicolumn{4}{|l|}{ Combined stem cell therapies } \\
\hline \multirow[t]{2}{*}{ - G-CSF and HGF } & hind limb ischemia in murine & Increased mobilization and recruitment of stem cells & {$[68]$} \\
\hline & & Increased angiogenesis and vasculogenesis & \\
\hline \multirow[t]{2}{*}{ - SCF and G-CSF } & MI in murine & Increased cardiac output & {$[69]$} \\
\hline & & Decreased arrhythmia & \\
\hline - EPCs with HGF & $\begin{array}{l}\text { Balloon-induced arterial injury in } \\
\text { hypercholesterolemic rats }\end{array}$ & $\begin{array}{l}\text { Increased proliferative, migratory and angiogenic } \\
\text { capabilities of EPCs }\end{array}$ & {$[70]$} \\
\hline \multicolumn{4}{|l|}{ Gene modified stem cell } \\
\hline - Modified MSCs by Bcl-2 & MI in rat & Increased anti-apoptotic ability & {$[74]$} \\
\hline \multirow[t]{2}{*}{ - Modified MSCs by Ang-I and Akt } & MI in rat & Increased angiogenesis & {$[75]$} \\
\hline & & Increased antiapoptotic activity & \\
\hline - Modified MSCs by heme-oxygenase- 1 & MI in mouse & Increased antiapoptotic and antioxidant activities & {$[76]$} \\
\hline - Modified MSCs by VEGF & MI in rat & Increased angiogenesis & {$[71]$} \\
\hline $\begin{array}{l}\text { - MSCs with combined genes } \\
\text { (VEGF and IGF-1) }\end{array}$ & MI in rat & Increased survival rate & {$[77]$} \\
\hline \multicolumn{4}{|l|}{ Preconditioning of } \\
\hline - MSCs with hypoxia & MI in mice & Increased its survival and paracrine mechanisms & {$[78]$} \\
\hline - MSCs with growth factors & MI in rat & Increased its apoptotic ability & {$[80]$} \\
\hline - MSCs with Diazoxide & MI in female rat & Increased its protection through NF- $\mathrm{KB}$ signaling & {$[81]$} \\
\hline \multicolumn{4}{|l|}{ Targeted delivery of therapy } \\
\hline $\begin{array}{l}\text { - Anti-myosin polyethylene } \\
\text { glycosylated liposomes }\end{array}$ & MI in rabbit & Increased infarct size reduction (fivefold) & {$[84]$} \\
\hline $\begin{array}{l}\text { - Anti-P-selectin conjugated } \\
\text { immunoliposomes containing VEGF }\end{array}$ & $\mathrm{MI}$ in rat & $\begin{array}{l}\text { Improvements in fractional shortening and } \\
\text { end-diastolic diameter }\end{array}$ & {$[85]$} \\
\hline
\end{tabular}

ischemic cardiomyopathy [3].

\section{Angiotensin-converting enzyme inhibitors}

Angiotensin-converting enzyme (ACE) inhibitors have been shown to promote mobilization of BM-EPCs after MI. ACE inhibitors enhance bone marrow stem cell migration mainly by increasing MMP-9 activity, thus stimulating the release of SCF [61]. Inhibition of ACE-mediated kinin degradation might also contribute to the increased numbers of circulating progenitor cells seen under ACE inhibition, but not under angiotensin II (Ang II) receptor blockade [62]. ACE inhibitor might therefore prevent adverse effects of Ang II, by counteracting its generation, as well as by protecting kinins which then can promote progenitor cells mobilization [48].

\section{Erythropoietin}

The EPO receptor is expressed in the heart mainly on endothelial cells, smooth muscle cells and cardiomyocytes. EPO has anti-apoptotic properties and is involved in cardiomyocyte proliferation. EPO stimulates neo-vascularization and has proliferative and mobilizing effects on BMSCs. The production of Epo is upregulated by hypoxia and is exclusively mediated via HIF-2 [63]. Similar to statins, EPO reduces the inflammatory reaction after stroke [64]. Although EPO has various positive effects on cardiac repair, 
an overload of EPO can lead to an elevation in blood viscosity and thrombolic events. In this regard, doses and frequencies of EPO administration should be investigated thoroughly [65].

\section{Other pharmacological agents}

In previous studies, calcium channel blockers; nifedipine and nisoldipine were found to induce the liberation of various populations of $\mathrm{CD} 34+$ progenitor cells along with improved endothelial function and oxidative stress status. These actions were independent from level of blood pressure attenuation $[62,66]$. The complement components; $\mathrm{C} 1 \mathrm{q}, \mathrm{C} 3 \mathrm{a}$ and $\mathrm{C} 5$ have been demonstrated to be crucially involved in the liberation of progenitor cells from bone marrow as well as their subsequent recruitment to target tissues [67]. Moreover, $\beta 2$ adrenergic stimulation promotes SC liberation and enhances mobilization induced by G-CSF [68].

\section{Combined stem cell therapies}

In a pre-clinical study, the combination of G-CSF and HGF were found to have a significant synergistic effect on potentiating angiogenesis and vasculogenesis by augmenting mobilization of SCs to peripheral circulation and their recruitment to the ischemic area [69]. The combination of SCF and G-CSF improved cardiac output and ameliorated arrhythmia in a murine MI model [70]. Moreover, ex vivo treatment of EPCs with HGF gene improved EPCs transplant efficiency for balloon-induced arterial injury in hypercholesterolemic rats and enhanced their homing and engraftment capabilities [71].

\section{Gene modified stem cell}

Multiple genetic engineering strategies have been applied to stem cells which were found to have better survival in ischemic tissues and to exert more powerful cytoprotection and/or pro-neovascularization effects compared with control stem cells. Many clinical trials using viral vectors to deliver required gene products have been terminated since the use of these vectors has induced adverse effects such as toxicities, immunogenicity and oncogenicity $[72,73]$. Potential side effects may also result from uncontrolled transgene expression [73]. MSCs have been used as a vehicle for gene therapy to deliver secreted gene products such as VEGF [74], HGF [50], bFGF [75] and SDF-1 [76].

The anti-apoptotic ability of modified MSCs increases by applying anti-apoptotic gene bcl-2 to MSCs [77]. Modified MSCs by Ang I and Akt were found to cooperatively meet the demands of angiogenesis and antiapoptosis to treat $\mathrm{MI}$ in rats [78]. HGF has also increased the ability of MSCs in angiogenesis, anti-apoptosis, and promotion of cell migration [6]. Heme-oxygenase-1 may increase cell survival of modified MSCs in ischemic myocardium through antiapoptotic and antioxidant activities [79]. Genes related to angiogenesis include VEGF, Ang I, FGF and HGF. MSCs taken from bone marrow and genetically engineered to produce VEGF were found to provide a cardioprotective effect as well as to induce angiogenesis in cardiac tissue [74]. The effect of single gene is limited. Therefore, a variety of gene combinations can be applied to meet different demands of therapy. Yau et al., [80] found that MSCs with combined genes (VEGF and IGF-1) to treat MI had the highest survival rate after one week. Furthermore, HIF is early released in response to hypoxia, which, in turn, activates pathways that increase oxygen delivery and promote adaptive pro-survival responses. This is pivotal for stem cell-mediated cardiac repair [2]. HIF-1 overexpression on EPCs promotes hypoxia-induced EPCs differentiation, proliferation and migration [81]. HIF has a central role in balancing energy availability and utilization in the heart. HIF therapy has been demonstrated to induce neo-angiogenesis in the ischemic heart and enhance neovascularization by increasing capillary density and thereby regional myocardial blood flow [82]. Therefore, targeting HIF instead of VEGF can activate more angiogenic factors at the same time resulting in intact neo-vascularization.

\section{Preconditioning of stem cells}

Preconditioning of MSCs in hypoxia prior to their transplantation has been shown to improve cell survival and stimulate paracrine mechanisms for heart repair [83]. Hypoxic preconditioning has been found to be able to start the PI3K/AKT signaling pathway and enhance the stability of HIF-1 to increase the antiapoptotic ability of MSCs [84]. In addition, some growth factors preconditioning can improve the ability of MSCs to resist apoptosis [85]. Diazoxide preconditioning can enhance the protective role of MSCs through the NF-KB signaling pathway [86]. Likewise, preconditioning of MSCs with SDF-1 [85], TGF- $a$ [87] or TGF- $\beta$ [88] led to decreased fibrosis after MI.

\section{Targeted delivery of therapy}

Novel targets for attenuation of LV remodelling and dysfunction include inflammatory pathway activation, oxidant stress pathway activation and MMP activation [3]. CSCs can be detected by several surface markers (e.g., c-kit, Sca-1, MDR1, IsI-1) [28]. Targeted drug delivery may be able to play a key role to provide an appropriate microenviroment that can support the regeneration of cardiac tissue lost after MI [1]. Anti-myosin polyethylene glycosylated liposomes preferentially bind to compromised infarcted heart vasculature by fusing with cell membranes using a plug and seal effect. This results in a fivefold infarct size reduction [89]. Anti-P-selectin conjugated immunoliposomes containing VEGF when injected immediately post-MI resulted in significant improvements in fractional shortening and end-diastolic diameter in rats [90].

\section{Conclusion}

Stem cell therapy represents a milestone in regenerative medicine. The use of stem cells has become pivotal for the 
development of new therapeutic strategies. To gain the optimal regenerative capacity for clinical application, we need to target and balance the orchestrating factors that are involved in stem cell-mediated cardiac repair. These include mobilization, incorporation, survival, differentiation and proliferation of stem cells.

The potential for magnifying stem cell-mediated paracrine effects using "genetically engineered", "preconditioned", "targeted" or "combined therapies" can provide promising options for enhancing stem cell therapy success while limiting adverse effects. It is hoped that these experimental trials will be eventually translated into successful treatment strategies in the clinical arena.

\section{Competing interests}

The author declares that he has no competing interests.

Publication history

Received: 06-May-2013 Revised: 17-Jul-2013

Accepted: 04-Oct-2013 Published: 21-Oct-2013

\section{References}

1. Scott RC, Crabbe D, Krynska B, Ansari R and Kiani MF. Aiming for the heart: targeted delivery of drugs to diseased cardiac tissue. Expert Opin Drug Deliv. 2008; 5:459-70. | Article | PubMed

2. Vandervelde $S$, van Luyn MJ, Tio RA and Harmsen MC. Signaling factors in stem cell-mediated repair of infarcted myocardium. J Mol Cell Cardiol. 2005; 39:363-76. | Article | PubMed

3. Landmesser U, Wollert KC and Drexler H. Potential novel pharmacological therapies for myocardial remodelling. Cardiovasc Res. 2009; 81:519-27. | Article | PubMed

4. Teo AK and Vallier L. Emerging use of stem cells in regenerative medicine. Biochem J. 2010; 428:11-23. | Article | PubMed

5. Blau HM, Brazelton TR and Weimann JM. The evolving concept of a stem cell: entity or function? Cell. 2001; 105:829-41. | Article | PubMed

6. Mingliang R, Bo Z and Zhengguo W. Stem cells for cardiac repair: status, mechanisms, and new strategies. Stem Cells Int. 2011; 2011:310928. | Article | PubMed Abstract | PubMed Full Text

7. Muller $\mathrm{R}$ and Lengerke $\mathrm{C}$. Patient-specific pluripotent stem cells: promises and challenges. Nat Rev Endocrinol. 2009; 5:195-203. | Article I PubMed

8. Laflamme MA and Murry CE. Regenerating the heart. Nat Biotechnol. 2005; 23:845-56. | Article | PubMed

9. Thomson JA, Itskovitz-Eldor J, Shapiro SS, Waknitz MA, Swiergiel JJ, Marshall VS and Jones JM. Embryonic stem cell lines derived from human blastocysts. Science. 1998; 282:1145-7. | Article | PubMed

10. de Vries RB, Oerlemans A, Trommelmans L, Dierickx K and Gordijn B. Ethical aspects of tissue engineering: a review. Tissue Eng Part $B$ Rev. 2008; 14:367-75. | Article | PubMed

11. Ratajczak MZ, Kucia M, Reca R, Majka M, Janowska-Wieczorek A and Ratajczak J. Stem cell plasticity revisited: CXCR4-positive cells expressing mRNA for early muscle, liver and neural cells 'hide out' in the bone marrow. Leukemia. 2004; 18:29-40. | Article | PubMed

12. Yoder MC and Williams DA. Matrix molecule interactions with hematopoietic stem cells. Exp Hematol. 1995; 23:961-7. | PubMed

13. Takahashi M, Li TS, Suzuki R, Kobayashi T, Ito H, Ikeda Y, Matsuzaki $\mathrm{M}$ and Hamano $\mathrm{K}$. Cytokines produced by bone marrow cells can contribute to functional improvement of the infarcted heart by protecting cardiomyocytes from ischemic injury. Am J Physiol Heart Circ Physiol. 2006; 291:H886-93. | Article | PubMed

14. Kamihata H, Matsubara H, Nishiue T, Fujiyama S, Tsutsumi Y, Ozono R, Masaki H, Mori Y, Iba O, Tateishi E, Kosaki A, Shintani S, Murohara T, Imaizumi T and Iwasaka T. Implantation of bone marrow mononuclear cells into ischemic myocardium enhances collateral perfusion and regional function via side supply of angioblasts, angiogenic ligands, and cytokines. Circulation. 2001; 104:1046-52. | Article | PubMed

15. Strauer BE, Yousef $M$ and Schannwell CM. The acute and long-term effects of intracoronary Stem cell Transplantation in 191 patients with chronic heARt failure: the STAR-heart study. Eur J Heart Fail. 2010; 12:721-9. | Article | PubMed

16. Bai Y, Sun T and Ye P. Age, gender and diabetic status are associated with effects of bone marrow cell therapy on recovery of left ventricular function after acute myocardial infarction: a systematic review and meta-analysis. Ageing Res Rev. 2010; 9:418-23. | Article I PubMed

17. Kinnaird T, Stabile E, Burnett MS, Shou M, Lee CW, Barr S, Fuchs S and Epstein SE. Local delivery of marrow-derived stromal cells augments collateral perfusion through paracrine mechanisms. Circulation. 2004; 109:1543-9. | Article | PubMed

18. Du YY, Zhou SH, Zhou T, Su H, Pan HW, Du WH, Liu B and Liu QM. Immuno-inflammatory regulation effect of mesenchymal stem cell transplantation in a rat model of myocardial infarction. Cytotherapy. 2008; 10:469-78. | Article | PubMed

19. Mirotsou M, Jayawardena TM, Schmeckpeper J, Gnecchi M and Dzau VJ. Paracrine mechanisms of stem cell reparative and regenerative actions in the heart. J Mol Cell Cardiol. 2011; 50:280-9. | Article | PubMed Abstract | PubMed Full Text

20. Dhein S, Garbade J, Rouabah D, Abraham G, Ungemach FR, Schneider K, Ullmann C, Aupperle H, Gummert JF and Mohr FW. Effects of autologous bone marrow stem cell transplantation on betaadrenoceptor density and electrical activation pattern in a rabbit model of non-ischemic heart failure. J Cardiothorac Surg. 2006; 1:17. | Article | PubMed Abstract | PubMed Full Text

21. Berry MF, Engler AJ, Woo YJ, Pirolli TJ, Bish LT, Jayasankar V, Morine $\mathrm{KJ}$, Gardner TJ, Discher DE and Sweeney HL. Mesenchymal stem cell injection after myocardial infarction improves myocardial compliance. Am J Physiol Heart Circ Physiol. 2006; 290:H2196-203. | Article | PubMed

22. Foley $A$ and Mercola M. Heart induction: embryology to cardiomyocyte regeneration. Trends Cardiovasc Med. 2004; 14:1215. | Article | PubMed

23. Urbich C, Aicher A, Heeschen C, Dernbach E, Hofmann WK, Zeiher AM and Dimmeler $S$. Soluble factors released by endothelial progenitor cells promote migration of endothelial cells and cardiac resident progenitor cells. J Mol Cell Cardiol. 2005; 39:733-42. | Article | PubMed

24. Yang Z, von Ballmoos MW, Faessler D, Voelzmann J, Ortmann J, Diehm N, Kalka-Moll W, Baumgartner I, Di Santo S and Kalka C. Paracrine factors secreted by endothelial progenitor cells prevent oxidative stress-induced apoptosis of mature endothelial cells. Atherosclerosis. 2010; 211:103-9. | Article | PubMed

25. Dawn B, Stein AB, Urbanek K, Rota M, Whang B, Rastaldo R, Torella D, Tang XL, Rezazadeh A, Kajstura J, Leri A, Hunt G, Varma J, Prabhu $\mathrm{SD}$, Anversa $\mathrm{P}$ and Bolli R. Cardiac stem cells delivered intravascularly traverse the vessel barrier, regenerate infarcted myocardium, and improve cardiac function. Proc Natl Acad Sci U S A. 2005; 102:376671. | Article | PubMed Abstract | PubMed Full Text

26. Beltrami AP, Barlucchi L, Torella D, Baker M, Limana F, Chimenti S, Kasahara H, Rota M, Musso E, Urbanek K, Leri A, Kajstura J, NadalGinard B and Anversa P. Adult cardiac stem cells are multipotent and support myocardial regeneration. Cell. 2003; 114:763-76. | Article | PubMed

27. David DA, Konrad U, Toru H: Aged cardiac stem cells could treat heart failure. American Heart Association Meeting Report 2010.

28. Chamuleau SA, Vrijsen KR, Rokosh DG, Tang XL, Piek JJ and Bolli $R$. Cell therapy for ischaemic heart disease: focus on the role of resident cardiac stem cells. Neth Heart J. 2009; 17:199-207. | Article | PubMed Abstract | PubMed Full Text

29. Chimenti I, Smith RR, Li TS, Gerstenblith G, Messina E, Giacomello A and Marban E. Relative roles of direct regeneration versus paracrine effects of human cardiosphere-derived cells transplanted into infarcted mice. Circ Res. 2010; 106:971-80. | Article | PubMed

30. Tang XL, Rokosh G, Sanganalmath SK, Yuan F, Sato H, Mu J, Dai S, Li 
C, Chen N, Peng Y, Dawn B, Hunt G, Leri A, Kajstura J, Tiwari S, Shirk $G$, Anversa $P$ and Bolli R. Intracoronary administration of cardiac progenitor cells alleviates left ventricular dysfunction in rats with a 30-day-old infarction. Circulation. 2010; 121:293-305. | Article | PubMed Abstract | PubMed Full Text

31. Hodgetts SI, Beilharz MW, Scalzo AA and Grounds MD. Why do cultured transplanted myoblasts die in vivo? DNA quantification shows enhanced survival of donor male myoblasts in host mice depleted of CD4+ and CD8+ cells or Nk1.1+ cells. Cell Transplant. 2000; 9:489-502. | PubMed

32. Hofmann M, Wollert KC, Meyer GP, Menke A, Arseniev L, Hertenstein B, Ganser A, Knapp WH and Drexler H. Monitoring of bone marrow cell homing into the infarcted human myocardium. Circulation. 2005; 111:2198-202. | Article | PubMed

33. Chen FM, Wu LA, Zhang M, Zhang R and Sun HH. Homing of endogenous stem/progenitor cells for in situ tissue regeneration: Promises, strategies, and translational perspectives. Biomaterials. 2011; 32:3189-209. | Article | PubMed

34. Sieveking DP and Ng MK. Cell therapies for therapeutic angiogenesis: back to the bench. Vasc Med. 2009; 14:153-66. | Article | PubMed

35. Jackson KA, Majka SM, Wang H, Pocius J, Hartley CJ, Majesky MW, Entman ML, Michael LH, Hirschi KK and Goodell MA. Regeneration of ischemic cardiac muscle and vascular endothelium by adult stem cells. J Clin Invest. 2001; 107:1395-402. | Article | PubMed Abstract | PubMed Full Text

36. Lionetti V, Cantoni S, Cavallini C, Bianchi F, Valente S, Frascari I, Olivi E, Aquaro GD, Bonavita F, Scarlata I, Maioli M, Vaccari V, Tassinari R, Bartoli A, Recchia FA, Pasquinelli G and Ventura C. Hyaluronan mixed esters of butyric and retinoic acid affording myocardial survival and repair without stem cell transplantation. J Biol Chem. 2010 285:9949-61. | Article | PubMed Abstract | PubMed Full Text

37. Ellison GM, Torella D, Dellegrottaglie S, Perez-Martinez C, Perez de Prado A, Vicinanza C, Purushothaman S, Galuppo V, laconetti C, Waring CD, Smith A, Torella M, Cuellas Ramon C, Gonzalo-Orden JM, Agosti V, Indolfi C, Galinanes M, Fernandez-Vazquez F and NadalGinard B. Endogenous cardiac stem cell activation by insulin-like growth factor-1/hepatocyte growth factor intracoronary injection fosters survival and regeneration of the infarcted pig heart. J Am Coll Cardiol. 2011; 58:977-86 | Article | PubMed

38. Wen Z, Mai Z, Zhang H, Chen Y, Geng D, Zhou S and Wang J. Local activation of cardiac stem cells for post-myocardial infarction cardiac repair. J Cell Mol Med. 2012; 16:2549-63. | Article | PubMed

39. Christopherson KW, 2nd, Uralil SE, Porecha NK, Zabriskie RC, Kidd SM and Ramin SM. G-CSF- and GM-CSF-induced upregulation of CD26 peptidase downregulates the functional chemotactic response of CD34+CD38- human cord blood hematopoietic cells. Exp Hematol. 2006; 34:1060-8. | Article | PubMed

40. Atluri P, Liao GP, Panlilio CM, Hsu VM, Leskowitz MJ, Morine KJ, Cohen JE, Berry MF, Suarez EE, Murphy DA, Lee WM, Gardner TJ, Sweeney $\mathrm{HL}$ and Woo YJ. Neovasculogenic therapy to augment perfusion and preserve viability in ischemic cardiomyopathy. Ann Thorac Surg. 2006; 81:1728-36. | Article | PubMed

41. Suda T, Suda J, Kajigaya S, Nagata S, Asano S, Saito M and Miura $Y$. Effects of recombinant murine granulocyte colony-stimulating factor on granulocyte-macrophage and blast colony formation. Exp Hematol. 1987; 15:958-65. | PubMed

42. Kang HJ, Kim HS, Zhang SY, Park KW, Cho HJ, Koo BK, Kim YJ, Soo Lee D, Sohn DW, Han KS, Oh BH, Lee MM and Park YB. Effects of intracoronary infusion of peripheral blood stem-cells mobilised with granulocyte-colony stimulating factor on left ventricular systolic function and restenosis after coronary stenting in myocardial infarction: the MAGIC cell randomised clinical trial. Lancet. 2004; 363:751-6. | Article | PubMed

43. Qian C, Schoemaker RG, van Gilst WH, Yu B and Roks AJ. Regenerative cell therapy and pharmacotherapeutic intervention in heart failure: Part 2: Pharmacological targets, agents and intervention perspectives. Neth Heart J. 2008; 16:337-43. | Article | PubMed Abstract | PubMed Full Text

44. Sano M, Minamino T, Toko H, Miyauchi H, Orimo M, Qin Y, Akazawa H, Tateno K, Kayama Y, Harada M, Shimizu I, Asahara T, Hamada H, Tomita S, Molkentin JD, Zou Y and Komuro I. p53-induced inhibition of Hif-1 causes cardiac dysfunction during pressure overload Nature. 2007; 446:444-8. | Article | PubMed

45. Ceradini DJ, Kulkarni AR, Callaghan MJ, Tepper OM, Bastidas N, Kleinman ME, Capla JM, Galiano RD, Levine JP and Gurtner GC. Progenitor cell trafficking is regulated by hypoxic gradients through HIF-1 induction of SDF-1. Nat Med. 2004; 10:858-64. | Article | PubMed

46. Heissig B, Hattori K, Dias S, Friedrich M, Ferris B, Hackett NR, Crystal RG, Besmer P, Lyden D, Moore MA, Werb Z and Rafii S. Recruitment of stem and progenitor cells from the bone marrow niche requires MMP-9 mediated release of kit-ligand. Cell. 2002; 109:625-37. | Article | PubMed Abstract | PubMed Full Text

47. Kucia M, Dawn B, Hunt G, Guo Y, Wysoczynski M, Majka M, Ratajczak J, Rezzoug F, Ildstad ST, Bolli R and Ratajczak MZ. Cells expressing early cardiac markers reside in the bone marrow and are mobilized into the peripheral blood after myocardial infarction. Circ Res. 2004; 95:1191-9. | Article | PubMed Abstract | PubMed Full Text

48. Krankel N, Spinetti G, Amadesi S and Madeddu P. Targeting stem cell niches and trafficking for cardiovascular therapy. Pharmacol Ther. 2011; 129:62-81. | Article | PubMed Abstract | PubMed Full Text

49. Presta M, Dell'Era P, Mitola S, Moroni E, Ronca R and Rusnati M. Fibroblast growth factor/fibroblast growth factor receptor system in angiogenesis. Cytokine Growth Factor Rev. 2005; 16:159-78. | Article I PubMed

50. Duan HF, Wu CT, Wu DL, Lu Y, Liu HJ, Ha XQ, Zhang QW, Wang H, Jia XX and Wang LS. Treatment of myocardial ischemia with bone marrow-derived mesenchymal stem cells overexpressing hepatocyte growth factor. Mol Ther. 2003; 8:467-74. | Article | PubMed

51. Gerber HP, Malik AK, Solar GP, Sherman D, Liang XH, Meng G, Hong $\mathrm{K}$, Marsters JC and Ferrara N. VEGF regulates haematopoietic stem cell survival by an internal autocrine loop mechanism. Nature. 2002; 417:954-8. | Article | PubMed

52. Semenza GL. Development of novel therapeutic strategies that target HIF-1. Expert Opin Ther Targets. 2006; 10:267-80. | Article PubMed

53. Papapetropoulos A, Garcia-Cardena G, Madri JA and Sessa WC. Nitric oxide production contributes to the angiogenic properties of vascular endothelial growth factor in human endothelial cells. J Clin Invest. 1997; 100:3131-9. | Article | PubMed Abstract | PubMed Full Text

54. Berthonneche C, Sulpice T, Boucher F, Gouraud L, de Leiris J, O'Connor $\mathrm{SE}$, Herbert JM and Janiak P. New insights into the pathological role of TNF-alpha in early cardiac dysfunction and subsequent heart failure after infarction in rats. Am J Physiol Heart Circ Physiol. 2004; 287:H340-50. | Article | PubMed

55. Watanabe T, Kawano Y, Kanamaru S, Onishi T, Kaneko S, Wakata $Y$, Nakagawa R, Makimoto A, Kuroda Y, Takaue $Y$ and Talmadge JE. Endogenous interleukin-8 (IL-8) surge in granulocyte colonystimulating factor-induced peripheral blood stem cell mobilization. Blood. 1999; 93:1157-63. | PubMed

56. Pruijt JF, Verzaal $P$, van Os R, de Kruijf EJ, van Schie ML, Mantovani $A$, Vecchi A, Lindley IJ, Willemze R, Starckx S, Opdenakker G and Fibbe WE. Neutrophils are indispensable for hematopoietic stem cell mobilization induced by interleukin-8 in mice. Proc Natl Acad Sci U S A. 2002; 99:6228-33. | Article | PubMed Abstract | PubMed Full Text

57. Besler C, Doerries C, Giannotti G, Luscher TF and Landmesser $U$. Pharmacological approaches to improve endothelial repair mechanisms. Expert Rev Cardiovasc Ther. 2008; 6:1071-82. | Article I PubMed

58. Weis M, Heeschen C, Glassford AJ and Cooke JP. Statins have biphasic effects on angiogenesis. Circulation. 2002; 105:739-45. | Article | PubMed

59. Landmesser U, Engberding N, Bahlmann FH, Schaefer A, Wiencke A, Heineke A, Spiekermann S, Hilfiker-Kleiner D, Templin C, Kotlarz D, Mueller M, Fuchs M, Hornig B, Haller $\mathrm{H}$ and Drexler H. Statininduced improvement of endothelial progenitor cell mobilization, myocardial neovascularization, left ventricular function, and survival after experimental myocardial infarction requires endothelial nitric oxide synthase. Circulation. 2004; 110:1933-9. | Article | PubMed

60. Landmesser $\mathrm{U}$ and Drexler H. Chronic heart failure: an overview 
of conventional treatment versus novel approaches. Nat Clin Pract Cardiovasc Med. 2005; 2:628-38. | Article | PubMed

61. Thum T, Fraccarollo D, Galuppo P, Tsikas D, Frantz S, Ertl G and Bauersachs J. Bone marrow molecular alterations after myocardial infarction: Impact on endothelial progenitor cells. Cardiovasc Res. 2006; 70:50-60. | Article | PubMed

62. Benndorf RA, Gehling UM, Appel D, Maas R, Schwedhelm E, Schlagner K, Silberhorn E, Hossfeld DK, Rogiers X and Boger R. Mobilization of putative high-proliferative-potential endothelial colony-forming cells during antihypertensive treatment in patients with essential hypertension. Stem Cells Dev. 2007; 16:329-38. | Article | PubMed

63. Westenbrink BD, Lipsic $E$, van der Meer $P$, van der Harst $P$, Oeseburg H, Du Marchie Sarvaas GJ, Koster J, Voors AA, van Veldhuisen DJ, van Gilst WH and Schoemaker RG. Erythropoietin improves cardiac function through endothelial progenitor cell and vascular endothelial growth factor mediated neovascularization. Eur Heart J. 2007; 28:2018-27. | Article | PubMed

64. Sun Y, Calvert JW and Zhang JH. Neonatal hypoxia/ischemia is associated with decreased inflammatory mediators after erythropoietin administration. Stroke. 2005; 36:1672-8. | Article | PubMed

65. Lee MS, Lee JS and Lee JY. Prevention of erythropoietin-associated hypertension. Hypertension. 2007; 50:439-45. | Article | PubMed

66. Sugiura $T$, Kondo T, Kureishi-Bando $Y$, Numaguchi $Y$, Yoshida $O$ Dohi Y, Kimura G, Ueda R, Rabelink TJ and Murohara T. Nifedipine improves endothelial function: role of endothelial progenitor cells. Hypertension. 2008; 52:491-8. | Article | PubMed

67. Lee HM, Wysoczynski M, Liu R, Shin DM, Kucia M, Botto M, Ratajczak $\mathrm{J}$ and Ratajczak MZ. Mobilization studies in complement-deficient mice reveal that optimal AMD3100 mobilization of hematopoietic stem cells depends on complement cascade activation by AMD3100stimulated granulocytes. Leukemia. 2010; 24:573-82. | Article | PubMed Abstract | PubMed Full Text

68. Spiegel A, Shivtiel S, Kalinkovich A, Ludin A, Netzer N, Goichberg P, Azaria Y, Resnick I, Hardan I, Ben-Hur H, Nagler A, Rubinstein M and Lapidot T. Catecholaminergic neurotransmitters regulate migration and repopulation of immature human CD34+ cells through Wht signaling. Nat Immunol. 2007; 8:1123-31. | Article | PubMed

69. Ieda Y, Fujita J, leda M, Yagi T, Kawada H, Ando K and Fukuda K. G-CSF and HGF: combination of vasculogenesis and angiogenesis synergistically improves recovery in murine hind limb ischemia. $J$ Mol Cell Cardiol. 2007; 42:540-8. | Article | PubMed

70. Kuhlmann MT, Kirchhof P, Klocke R, Hasib L, Stypmann J, Fabritz L, Stelljes M, Tian W, Zwiener M, Mueller M, Kienast J, Breithardt $\mathrm{G}$ and Nikol S. G-CSF/SCF reduces inducible arrhythmias in the infarcted heart potentially via increased connexin 43 expression and arteriogenesis. J Exp Med. 2006; 203:87-97. | Article | PubMed Abstract | PubMed Full Text

71. Song MB, Yu XJ, Zhu GX, Chen JF, Zhao G and Huang L. Transfection of HGF gene enhances endothelial progenitor cell (EPC) function and improves EPC transplant efficiency for balloon-induced arterial injury in hypercholesterolemic rats. Vascul Pharmacol. 2009; 51:20513. | Article | PubMed

72. Mitchell JB, McIntosh K, Zvonic S, Garrett S, Floyd ZE, Kloster A, Di Halvorsen Y, Storms RW, Goh B, Kilroy G, Wu X and Gimble JM. Immunophenotype of human adipose-derived cells: temporal changes in stromal-associated and stem cell-associated markers. Stem Cells. 2006; 24:376-85. | Article | PubMed

73. Baum C, Dullmann J, Li Z, Fehse B, Meyer J, Williams DA and von Kalle C. Side effects of retroviral gene transfer into hematopoietic stem cells. Blood. 2003; 101:2099-114. | Article | PubMed

74. Matsumoto R, Omura T, Yoshiyama M, Hayashi T, Inamoto S, Koh KR, Ohta K, Izumi Y, Nakamura Y, Akioka K, Kitaura Y, Takeuchi K and Yoshikawa J. Vascular endothelial growth factor-expressing mesenchymal stem cell transplantation for the treatment of acute myocardial infarction. Arterioscler Thromb Vasc Biol. 2005; 25:116873. | Article | PubMed

75. Song H, Kwon K, Lim S, Kang SM, Ko YG, Xu Z, Chung JH, Kim BS, Lee $H$, Joung B, Park S, Choi D, Jang Y, Chung NS, Yoo KJ and Hwang $\mathrm{KC}$. Transfection of mesenchymal stem cells with the FGF-2 gene improves their survival under hypoxic conditions. Mol Cells. 2005; 19:402-7. | PubMed

76. Zhang M, Mal N, Kiedrowski M, Chacko M, Askari AT, Popovic ZB, Koc ON and Penn MS. SDF-1 expression by mesenchymal stem cells results in trophic support of cardiac myocytes after myocardial infarction. FASEB J. 2007; 21:3197-207. | Article | PubMed

77. Li W, Ma N, Ong LL, Nesselmann C, Klopsch C, Ladilov Y, Furlani D, Piechaczek C, Moebius JM, Lutzow K, Lendlein A, Stamm C, Li RK and Steinhoff G. Bcl-2 engineered MSCs inhibited apoptosis and improved heart function. Stem Cells. 2007; 25:2118-27. | Article | PubMed

78. Shujia J, Haider HK, Idris NM, Lu G and Ashraf M. Stable therapeutic effects of mesenchymal stem cell-based multiple gene delivery for cardiac repair. Cardiovasc Res. 2008; 77:525-33. | Article | PubMed

79. Tang YL, Tang Y, Zhang YC, Qian K, Shen L and Phillips MI. Improved graft mesenchymal stem cell survival in ischemic heart with a hypoxia-regulated heme oxygenase-1 vector. J Am Coll Cardiol. 2005; 46:1339-50. | Article | PubMed

80. Yau TM, Kim C, Li G, Zhang Y, Weisel RD and Li RK. Maximizing ventricular function with multimodal cell-based gene therapy. Circulation. 2005; 112:1123-8. | Article | PubMed

81. Jiang $M$, Wang B, Wang C, He B, Fan $H$, Guo TB, Shao $Q$, Gao L and Liu $Y$. Angiogenesis by transplantation of HIF-1 alpha modified EPCs into ischemic limbs. J Cell Biochem. 2008; 103:321-34. | Article | PubMed

82. Shyu KG, Wang MT, Wang BW, Chang CC, Leu JG, Kuan P and Chang H. Intramyocardial injection of naked DNA encoding HIF-1alpha/VP16 hybrid to enhance angiogenesis in an acute myocardial infarction model in the rat. Cardiovasc Res. 2002; 54:576-83. | Article I PubMed

83. Uemura $\mathrm{R}, \mathrm{Xu} \mathrm{M}, \mathrm{Ahmad} \mathrm{N}$ and Ashraf $\mathrm{M}$. Bone marrow stem cells prevent left ventricular remodeling of ischemic heart through paracrine signaling. Circ Res. 2006; 98:1414-21. | Article | PubMed

84. Hu X, Yu SP, Fraser JL, Lu Z, Ogle ME, Wang JA and Wei L. Transplantation of hypoxia-preconditioned mesenchymal stem cells improves infarcted heart function via enhanced survival of implanted cells and angiogenesis. J Thorac Cardiovasc Surg. 2008; 135:799-808. | Article | PubMed

85. Pasha Z, Wang Y, Sheikh R, Zhang D, Zhao T, Ashraf M: Preconditioning enhances cell survival and differentiation of stem cells during transplantation in infracted myocardium. Cardiovasc Res 2008, 77: 134-142. | Article

86. Afzal MR, Haider H, Idris NM, Jiang S, Ahmed RP and Ashraf M. Preconditioning promotes survival and angiomyogenic potential of mesenchymal stem cells in the infarcted heart via NF-kappaB signaling. Antioxid Redox Signal. 2010; 12:693-702. | Article | PubMed Abstract | PubMed Full Text

87. Herrmann JL, Wang Y, Abarbanell AM, Weil BR, Tan J and Meldrum DR. Preconditioning mesenchymal stem cells with transforming growth factor-alpha improves mesenchymal stem cell-mediated cardioprotection. Shock. 2010; 33:24-30. | Article | PubMed

88. Li TS, Hayashi M, Ito H, Furutani A, Murata T, Matsuzaki M and Hamano K. Regeneration of infarcted myocardium by intramyocardial implantation of ex vivo transforming growth factorbeta-preprogrammed bone marrow stem cells. Circulation. 2005; 111:2438-45. | Article | PubMed

89. Khaw BA, DaSilva J and Hartner WC. Cytoskeletal-antigen specific immunoliposome-targeted in vivo preservation of myocardial viability. J Control Release. 2007; 120:35-40. | Article | PubMed

90. Scott RC, Rosano JM, Ivanov Z, Wang B, Chong PL, Issekutz AC, Crabbe $\mathrm{DL}$ and Kiani MF. Targeting VEGF-encapsulated immunoliposomes to MI heart improves vascularity and cardiac function. FASEB J. 2009; 23:3361-7. | Article | PubMed

\section{Citation:}

Ahmed LA. Stem cells and cardiac repair: alternative and multifactorial approaches. J Regen Med Tissue Eng. 2013; 2:8. http://dx.doi.org/10.7243/2050-1218-2-8 